\title{
Agricultural tractor performance fueled with proportions of biodiesel ${ }^{1}$
}

\author{
Priscila Sawasaki Iamaguti ${ }^{2}$, Afonso Lopes ${ }^{2}$, Antonio Alves Pinto ${ }^{2 *}(\mathbb{D}$, \\ Thyago Augusto Medeiros Lira², Leomar Paulo de Lima ${ }^{3}$
}

10.1590/0034-737X202269010001

\begin{abstract}
Among the fuel sources used nowadays, biofuels stand out for being renewable and biodegradable. In this sense, this work aimed to evaluate the performance and smoke opacity of an agricultural tractor in soil tillage activities, depending on the biodiesel blends and the engine rotation. Were used six blends of soy (S) and murumuru (M) biodiesel and seven engine rotation speeds. The results showed a directly proportional relationship between the drawbar power and the engine rotation decrease. Regarding hourly volumetric and weighted consumption, both presented the same behavior: the lowest consumptions were reached when using the two highest proportions of murumuru biodiesel, yet the highest specific consumption was obtained when using the $90 \mathrm{M} 10 \mathrm{~S}$ blend. Furthermore, the lowest opacity was emitted when the tractor was fueled with the three blends having the highest proportions of murumuru biodiesel. Blends with more than $80 \%$ of murumuru biodiesel promote lower fuel consumption than blends with a higher concentration of soy biodiesel. Regardless of the biodiesel blend, the traction force at the drawbar is directly proportional to an increase in the engine rotation speed. In smoke opacity, mixtures with more than $70 \%$ murumuru biodiesel promote less opacity than mixtures with a higher concentration of soy biodiesel.
\end{abstract}

Keywords: Astrocaryum murumuru; fuel consumption; Glycine max; smoke opacity.

\section{INTRODUCTION}

According to the International Energy Agency (IEA, 2019), a global energy transition is underway from fossil fuels to renewable energy sources. In addition, this transition could open up new growth opportunities for renewable resources, including biofuels, which could triple their consumption by 2040. According to the 2019 TenYear Energy Plan, biodiesel consumption in Brazil will grow $94 \%$ by 2029 . The Brazilian market consumed 5.86 billion liters of biodiesel in 2019, which will increase to around 5.53 billion liters, totaling more than 11.38 billion liters consumed in 2024 (EPE, 2019).

Biodiesel has become important to compressionignition engines because it is relatively easy to produce. Vegetable oils, in their natural states, can be used as fuel for internal combustion engines, but occasionally cause increased damage (wear and tear) to the engine and, consequently, poor combustion. The development of biofuels for transportation has been based on converting plant sugar into ethanol through fermentation and optimizing vegetable oils by transesterification (Guimarães et al., 2018).

Biodiesel is known by its several advantages such as biodegradability and being made fully of biobased materials, high viscosity, low explosion risks, low emission of particulate matter, and complete combustion, furthermore, since it has neither aromatic nor sulphur compounds, it causes less impact to the greenhouse effect (Pour et al., 2018).

Diesel engines are essential to many transportation and agricultural activities due to their efficiency, durability, torque at low rotations. In agriculture, its use is unquestionable because of its strength, reliability, higher torque, and longevity, aside from its lower consumption

\footnotetext{
Submitted on May $27^{\text {th }}, 2020$ and accepted on February 18 $8^{\text {th }}, 2021$.

'This work is part of the first author's Master Dissertation.

${ }^{2}$ Universidade Estadual Paulista Júlio de Mesquita Filho, Campus de Jaboticabal, Jaboticabal, São Paulo, Brazil. priiamaguti@hotmail.com; afonso.lopes@unesp.br; antonioalvesunesp@gmail.com; thyagolira@ hotmail.com

3nstituto Federal Triângulo Mineiro, Uberlândia, Minas Gerais, Brazil. leomar@iftm.edu.br

*Corresponding author: antonioalvesunesp@gmail.com
} 
and higher yield (efficiency), when compared to Otto cycle engines. Agricultural tractors are machines idealized to perform various tasks, specifically related to soil and traction work, while attached to the different tools available (Cutini \& Bisaglia, 2016).

Overall, engine operational performance is measured by the following variables: traction force, hourly fuel consumption, specific consumption, and traveling speed. The quantification of consumed fuel is extremely important to estimate engine yield and evaluate tractor efficiency (Damanauskas et al., 2015).

According to data from EPE (2019) more than 60\% of the biodiesel produced in Brazil comes from soy, however, with the increase in the price of this commodity in the international market, producers have increasingly opted for the export of their grain, putting at risk the production of biodiesel. Therefore, researchers have sought to study a variety of potential molecules to produce new fuels or even improve existing ones, in order to develop vehiclecompatible fuel conversion technologies.

In this sense, this work aimed to evaluate the performance and smoke opacity of an agricultural tractor in soil tillage activities, depending on the biodiesel blends and the engine rotation.

\section{MATERIALAND METHODS}

The experiment was conducted at the Biofuel and Machine Assay Laboratory - BIOEM, of the Bioenergy Research Institute (IPBEN, FCAV/UNESP), Department of Rural Engineering at the State University of São Paulo (UNESP), Jaboticabal Campus - São Paulo, Brazil. The area is located beside the Prof. Paulo Donato Castellane Access Road, km 5, at the geographic coordinates of $21^{\circ} 15^{\prime} \mathrm{S}, 48^{\circ} 18^{\prime} \mathrm{W}$ and an average altitude of $570 \mathrm{~m}$. The region has an average annual temperature of $22.2{ }^{\circ} \mathrm{C}$, average annual rainfall of $1.425 \mathrm{~mm}$, relative humidity of $71 \%$, and an atmospheric pressure of $94.3 \mathrm{kPa}$. The climate, according to the Köeppen classification, is classified as a Cwa type, which stands for tropical humid with rainy summers and dry winters.

Six blends were used, each with different proportions of refined soy (Glycine max L. Merr.) and refined murumuru (Astrocaryum mигитиги Mart.) biodiesels: S90M10, S80M20, S70M30, S10M90, S20M80, and S30M70, the numbers indicating the percentage of biodiesel in the blend and the letters, the origin ( $\mathrm{S}$ indicates the soy biodiesel and $\mathrm{M}$ the murumuru biodiesel). The biofuels were processed and provided by the Clean Technology Development Laboratory (LADETEL), University of São Paulo (USP), Ribeirão Preto Campus - São Paulo, Brazil, in partnership with FCAV/UNESP.

Two tractors were used in the experiment: the test tractor and the brake tractor. The test tractor was manufactured by Valtra (model BM 125i) and equipped with a turbocharged engine and intercooler, $4 \times 2$ with an auxiliary front-wheel drive (FWD). The engine has a power of $91.9 \mathrm{~kW}(125 \mathrm{HP})$ at $2300 \mathrm{rpm}$, according to the ISO1585 standard (ISO 2010), and a total weight of $5400 \mathrm{~kg}$ with ballast, distributed between 40 and $60 \%$ for the front and rear axles, respectively. In addition, it had a weight-topower ratio of $76 \mathrm{~kg} \mathrm{~kW}-1$ (56 kg HP-1) and tires 14.9-26 on the front axle and 23.1-30 on the rear axle, all with adequate tire pressure, as recommended by the manufacturer.

The brake tractor used was a Valmet, model 118-4, 4x2, with auxiliary front-wheel drive (FWD), engine power 82.43 $\mathrm{kW}(112 \mathrm{HP})$ at $2,400 \mathrm{rpm}$, the total weight of $7,310 \mathrm{~kg}$ with ballast, distributed 40 and $60 \%$ for the front and rear axle, respectively, and tires 14.9-28 in the front and 23.1-30 tires on the rear axle. As its only function was to provide constant draw force to the drawbar, this tractor was attached by a steel cable to the test. This tractor engine remained off, in the combination of fourth gear (range L), and auxiliary front-wheel drive (FWD) activated, as to obtain the necessary working speed and weight for the entire duration of the experiment.

Aiming at defining the highest technically-viable traction force the test tractor could produce at the drawbar, we conducted a preliminary test called the pilot experiment, which consisted of scarification of an attached area. A Marchesan chisel plow, model AST/MATIC 7, with a total weight of $1,400 \mathrm{~kg}$ and containing five rods $14-\mathrm{cm}$ apart from each other, with $8 \mathrm{~cm}$ wide tips, with no "wings", cutoff wheels for each rod, automatic shutdown security system and clod crushing roller. The plow was regulated so it would work at a depth of $30 \mathrm{~cm}$ and 1.5 space/depth ratio. The necessary traction force to perform this task was about $23 \mathrm{kN}$ and the $10 \%$ wheelslip.

The main test was divided into two parts. The first part (I) was conducted at field conditions to assess the volumetric, weighted and specific fuel consumptions. For the performance test, the test tractor was attached to a load cell, wheelslip measurer, radar unit, data acquisition system and a prototype of a fuel consumption measurer, as described by Lopes (2006). After each test, all the biodiesel not consumed was drained from the tanks, filters, and tubes, therefore, avoiding the contamination of the following test.

Volumetric fuel consumption $(\mathrm{mL})$ was measured in each plot, by subtracting the total returned volume (found in injection nozzles and pump) from the total fuel supply at the entrance of the injection pump. Having this data, we could determine the hourly (volumetric and weighted) and specific consumptions. All experimental plots were 40-m long and spaced in $15 \mathrm{~m}$ from each other for maneuvers, machine traffic, and mechanized assembly stabilization. At the end of each measurement, the entire 
supply system was drained to avoid contaminating the following treatment. Furthermore, after substituting the fuel, the engine remained on for ten minutes before the beginning of the next test.

The experiment was performed in a completely randomized design, in a $6 \times 7 \times 4$ factorial scheme, totaling 168 treatments. The combinations used were six different biofuel blends (S90M10, S80M20, S70M30, S10M90, S20M80 and S30M70), seven engine rotation speeds (1800, 1900, 2000, 2100, 2200, 2400 and $2600 \mathrm{rpm}$ ), and four repetitions with the test tractor working in the third gear of group L.

Hourly volumetric consumption was calculated based on the volume consumption and course time in each plot, as shown in the following equation:

$\mathrm{HVC}=\left(\frac{\mathrm{Fvs}-\mathrm{TVs}}{\mathrm{t}}\right) * 3.6$

In which,

HVC $=$ Hourly volumetric consumption, $\mathrm{L} \mathrm{h}^{-1}$;

Fvs = Fuel supply volume at the entrance of the injection pump, $\mathrm{mL}$;

$\mathrm{Tvr}=$ Total volume returned from the injection nozzles and pump, $\mathrm{mL}$;

$\mathrm{T}=$ course time of plot, $\mathrm{s}$, and;

$3.6=$ conversion factor

To calculate the weighted hourly consumption, we considered the influence of fuel supply density and fuel return density while testing, as shown in the following equation:

$\mathrm{WHC}=\left(\frac{\mathrm{Sfv} * \mathrm{Sfd}-\mathrm{Rfv} * \mathrm{Rfd}}{\mathrm{t}}\right) * 3.6$

In which,

WHC = weighted hourly consumption, $\mathrm{kg} \mathrm{h}^{-1}$;

$\mathrm{Sfv}=$ supply fuel volume, $\mathrm{mL}$;

$\mathrm{Sfd}=$ supply fuel density, $\mathrm{kg} \mathrm{m}^{-3}$;

$\mathrm{Rfv}=$ return fuel volume, $\mathrm{mL}$;

$\mathrm{Rfd}=$ return fuel density, $\mathrm{kg} \mathrm{m}^{-3}$;

$\mathrm{T}=$ course time of plot, $\mathrm{s}$, and

$0.0036=$ conversion factor

Specific consumption was expressed in unit of mass by power unit required at the drawbar, as in the following equation:

$\mathrm{SFC}=\left(\frac{\mathrm{WHP}}{\mathrm{Pd}}\right) * 1000$

In which,

$\mathrm{SFC}=$ Specific consumption, $\mathrm{g} \mathrm{kWh}^{-1}$;

WHC $=$ Weighted hourly consumption, $\mathrm{kg} \mathrm{h}^{-1}$;
$\mathrm{Pd}=$ power at the drawbar, $\mathrm{kW}$;

$1000=$ conversion factor.

Test II was conducted in a motionless manner, according to the free acceleration method of the NBR 13037 (ABNT, 2001), which consists of maintaining the throttle to a maximum gear for 3 to 5 seconds; herein the developed power is solely absorbed by inertia in the mechanical parts of the engine (clutch, primary "tree" of the gearbox).

The opacity measurements were taken in $\mathrm{K}$ (coefficient of light absorption), expressed in $\mathrm{m}^{-1}$ unit. Was used a partial flow light absorption opacimeter, of Tecnomotor brand, model TM 133, which is compatible with the standards NBR 13037, Inmetro, CEE 72/306. The opacimeter was connected to the serial controller of brand Tecnomotor, model TM 616, which received the sensor signals and converted them into a unit of measurement. Such equipment serves to export the converted data to computers by means of a serial connection, whose interface is the software called IGOR (TECNOMOTOR, 2012).

This test was performed in completely randomized delineation $6 \times 12$, totaling 72 treatments. The six different blend proportions of biofuels used were the same used in test I, but only three repetitions were conducted, with seven to ten replications each. At the end of each plot, the supply system was totally drained after each measurement to avoid contaminating the following treatment.

The data were put into tables and submitted to a variance analysis and to Tukey's mean comparison test (at 5\% probability), as suggested by Barbosa \& Maldonado Júnior (2015). In this study, the variance analysis (F test) was used to select the equation model of the greatest significant exponent. For specific consumption and smoke opacity, we studied the suitable regression adjustment model to explain the behavior of these variables in relation to the biodiesel proportions.

\section{RESULTS AND DISCUSSION}

There was no interaction between blends and engine speed for fuel consumption (Table 1). Regarding biodiesel blends, there was a statistical difference of $5 \%$ in hourly volumetric consumption (HVC) and $1 \%$ in weighted hourly consumption (WHC) and specific consumption (SFC), with the lowest consumption in the blends 20S80M end 10S90M for HVC and WHC, and 90S10M for SFC (323,31 $\left.\mathrm{g} \mathrm{kWh}^{-1}\right)$. According to Fiorese et al. (2015a), in agricultural engines, the highest fuel consumption is obtained when the engine is running close to its maximum capacity and with the accelerator fully depressed; as engine speed decreases, consumption also decreases. 
Reis et al. (2013) found similar results when evaluated the use of soy biodiesel in a diesel engine with different electric-charge engine demand (500; 1000; 1500 and 2000 $\mathrm{W})$. They observed an interaction between the electric charges and found an increasing volumetric hourly consumption with biodiesel concentration, and the applied charge was increased in the system. Relatively low calorific values, high viscosity, and high density of biodiesel blends may be the reason for small increases in specific consumption results, which is a parameter for comparing tractors, and the higher the consumption, the lower the energy conversion efficiency of the fuel (Behcet, 2011).

For engine speeds, all mixing results were statistically different and consumption increased as speed increased, with less SVC and WHC at $1800 \mathrm{rpm}$ and SFC between 2000 and 2400rpm (Table 1). According to Oliveira (2016), when studying the weighted consumption according to the type of fuel and the engine rotation speed, the consumption of soybean and murumuru biodiesel was the lowest for $1,800 \mathrm{rpm}$, but remained stable for 1900 and 2,000 rpm. however, higher revs are less efficient due to the higher energy expenditure, which occurs due to the increased friction between the mobile and stationary components of the engine and the reduced fuel combustion time (Márquez, 2012).
Siqueira et al. (2013) observed the same while studying several blends of diesel oil (DO) and reusable soy oil (RSO) to evaluate the yield of an agricultural tractor; the higher the power, the lower the specific consumption. Paula et al. (2016) also found similar results when using diesel fuel and soy biodiesel in agricultural tractors. The variance analysis of rotation speed and specific fuel consumption indicated significant differences, besides a fuel and rotation interaction.

As seen in Table 1, there was a significant interaction for drawbar power, which is why it was necessary to analyze the factors through a further statistical breakdown table (Table 2).

Table 2 shows the biodiesel blend factor (lines) and the drawbar power as directly proportional to decreases in engine rotation speed. Therefore, as the rotation speed increased the drawbar power also increased for all six biodiesel blends, as engine-produced torque is duplicated and transmitted to the driving wheels, and then converted into a tangential force to be made available to the drawbar. For Linares et al. (2006), besides pulling the equipment, the produced torque is also used to overcome the rolling resistance for tractor mobility.

Fiorese et al. (2015b) observed that as the traction force increased, the drive axles was demanded more

Table 1: Summary of the variance analysis and mean comparison test for the variables: power at the drawbar (kW), hourly volumetric consumption (HVC), weighted hourly consumption (WHC) and specific consumption (SFC)

\begin{tabular}{|c|c|c|c|c|}
\hline Factors & $\mathbf{P d}(\mathbf{k W})$ & HVC $\left(\mathbf{L ~ h}^{-1}\right)$ & WHC $\left(\mathrm{kg} \mathrm{h}^{-1}\right)$ & $\operatorname{SFC}\left(\mathrm{g} \mathrm{kWh}^{-1}\right)$ \\
\hline \multicolumn{5}{|c|}{ Biodiesel Blends (BM) } \\
\hline 90S10M & 43.40 & $14.45 \mathrm{~b}$ & $12.82 \mathrm{~b}$ & 297.13 a \\
\hline $80 \mathrm{~S} 20 \mathrm{M}$ & 42.17 & $14.38 \mathrm{~b}$ & $12.73 \mathrm{~b}$ & $303.42 \mathrm{ab}$ \\
\hline $70 \mathrm{~S} 30 \mathrm{M}$ & 40.98 & $14.31 \mathrm{~b}$ & $12.67 \mathrm{~b}$ & $310.76 \mathrm{~b}$ \\
\hline $30 \mathrm{~S} 70 \mathrm{M}$ & 41.54 & $14.65 \mathrm{~b}$ & $12.85 \mathrm{~b}$ & $312.06 \mathrm{~b}$ \\
\hline $20 \mathrm{~S} 80 \mathrm{M}$ & 36.38 & $13.38 \mathrm{a}$ & $11.24 \mathrm{a}$ & $310.43 \mathrm{~b}$ \\
\hline $10 \mathrm{~S} 90 \mathrm{M}$ & 35.92 & $13.15 \mathrm{a}$ & $11.55 \mathrm{a}$ & $323.31 \mathrm{c}$ \\
\hline \multicolumn{5}{|c|}{ Engine Rotation (ER) } \\
\hline 2600 & 60.93 & $21.27 \mathrm{~g}$ & $18.86 \mathrm{~g}$ & $310.32 \mathrm{bc}$ \\
\hline 2400 & 49.86 & $17.09 \mathrm{f}$ & $14.82 \mathrm{f}$ & $298.26 \mathrm{a}$ \\
\hline 2200 & 41.08 & $14.29 \mathrm{e}$ & $12.53 \mathrm{e}$ & $306.30 \mathrm{ab}$ \\
\hline 2100 & 37.52 & $13.09 \mathrm{~d}$ & $11.44 \mathrm{~d}$ & $306.39 \mathrm{ab}$ \\
\hline 2000 & 33.65 & $11.77 \mathrm{c}$ & $10.29 \mathrm{c}$ & $306.92 \mathrm{ab}$ \\
\hline 1900 & 30.11 & $10.9 \mathrm{~b}$ & $9.54 \mathrm{~b}$ & $318.44 \mathrm{c}$ \\
\hline \multirow[t]{2}{*}{1800} & 27.31 & $9.95 \mathrm{a}$ & $8.68 \mathrm{a}$ & $319.99 \mathrm{c}$ \\
\hline & F TEST & & & \\
\hline BM & $209.25 * *$ & $20.46^{*}$ & $36.56^{* *}$ & $15.97 * *$ \\
\hline ER & $2553.57 * *$ & $702.57 * *$ & $757.65^{* *}$ & $10.05^{* *}$ \\
\hline BMxER & $2.34 * *$ & $0.866^{\mathrm{NS}}$ & $1.00^{\mathrm{NS}}$ & $0.87^{\mathrm{NS}}$ \\
\hline $\mathrm{CV}(\%)$ & 2.48 & 4.51 & 4.42 & 3.27 \\
\hline Mean & 40.07 & 14.05 & 12.31 & 309.52 \\
\hline
\end{tabular}

Means followed by the same letter in the columns do not vary between them, according to the Tukey's test at 5\% probability. **: significant $(\mathrm{P}<0.01)$; *: significant $(\mathrm{P}<0.05)$; NS not significant; C.V: coefficient of variation. 
Table 2: Statistical breakdown of the interaction between fuel type and engine rotation for the power at the drawbar

\begin{tabular}{lccccccc}
\hline $\begin{array}{l}\text { Biodiesel } \\
\text { Blends }\end{array}$ & $\mathbf{2 6 0 0}$ & $\mathbf{2 4 0 0}$ & $\mathbf{2 2 0 0}$ & $\mathbf{2 1 0 0}$ & $\mathbf{2 0 0 0}$ & $\mathbf{1 9 0 0}$ & $\mathbf{1 8 0 0}$ \\
\cline { 2 - 7 } & $\mathbf{2 6 0 0}$ & Engine Rotation $(\mathbf{r p m})$ \\
$90 \mathrm{~S} 10 \mathrm{M}$ & $65.92 \mathrm{Ab}$ & $53.30 \mathrm{Aab}$ & $44.32 \mathrm{Aab}$ & $41.07 \mathrm{Aab}$ & $36.16 \mathrm{Aab}$ & $33.20 \mathrm{Aa}$ & $29.84 \mathrm{Aa}$ \\
$80 \mathrm{~S} 20 \mathrm{M}$ & $63.29 \mathrm{Ab}$ & $52.20 \mathrm{Aab}$ & $43.19 \mathrm{Aab}$ & $39.18 \mathrm{Aab}$ & $35.83 \mathrm{Aab}$ & $32.47 \mathrm{Aab}$ & $29.04 \mathrm{Aa}$ \\
$70 \mathrm{~S} 30 \mathrm{M}$ & $61.96 \mathrm{Ab}$ & $51.11 \mathrm{Aab}$ & $41.84 \mathrm{Aab}$ & $38.51 \mathrm{Aab}$ & $33.61 \mathrm{Aab}$ & $31.25 \mathrm{Aab}$ & $28.7 \mathrm{Aa}$ \\
$30 \mathrm{~S} 70 \mathrm{M}$ & $63.59 \mathrm{Ab}$ & $51.79 \mathrm{Aab}$ & $43.23 \mathrm{Aab}$ & $38.93 \mathrm{Aab}$ & $35.38 \mathrm{Aab}$ & $29.88 \mathrm{Aa}$ & $27.98 \mathrm{Aa}$ \\
$20 \mathrm{~S} 80 \mathrm{M}$ & $55.68 \mathrm{Aa}$ & $45.85 \mathrm{Aa}$ & $36.72 \mathrm{Aa}$ & $34.07 \mathrm{Aa}$ & $30.08 \mathrm{Aa}$ & $27.26 \mathrm{Aa}$ & $25.04 \mathrm{Aa}$ \\
$10 \mathrm{~S} 90 \mathrm{M}$ & $55.14 \mathrm{Aa}$ & $44.91 \mathrm{Aa}$ & $37.20 \mathrm{Aa}$ & $33.34 \mathrm{Aa}$ & $30.85 \mathrm{Aa}$ & $26.63 \mathrm{Aa}$ & $23.41 \mathrm{Aa}$ \\
\hline
\end{tabular}

Means followed by the same capital letter in the column and lower-case letter in the line do not vary between them, according to the Tukey's test at $5 \%$ probability.

torque, which is represented by a linear increase. According to Almeida et al. (2010), in order to increase traveling speed, rotation speed must be increased, resulting in the reduction of engine torque and an increase in fuel consumption. In other words, from the $1500 \mathrm{rpm}$ range on, the torque reserve decreases, and the required power at the drawbar and the fuel consumption increase as rotation speed increases.

According to Table 2, regarding all engine rotation speeds (columns) no significant differences for the drawbar traction power were found. Siqueira et al. (2013) also found similar results when assessing the performance of agricultural tractors fueled with blends of diesel oil (DO) and reusable soy oil (RSO). In this case, the traction force was the same for all blends. Contrarily, Paula et al. (2016) worked with a Green Horse agricultural tractor (model 204) to find the performance curves of blends of diesel and biodiesel in the proportions B2, B5, B20, and $\mathrm{B} 100$. The interaction of fuel blends and rotation speed was highly significant, confirming the performance difference of the engine in relation to the rotation rate and the blends used.

The results of the opacity emissions differed significantly from each other $(\mathrm{p}<0.01)$, obtaining lower

Table 3: Summary of the variance analysis and mean comparison test for the smoke opacity variable $\left(\mathrm{m}^{-1}\right)$

\begin{tabular}{lc}
\hline Biofuel Blend (MB) & Opacity $\left(\mathbf{m}^{-1}\right)$ \\
\hline $90 S 10 \mathrm{M}$ & $1.51 \mathrm{~d}$ \\
$80 \mathrm{~S} 20 \mathrm{M}$ & $1.32 \mathrm{c}$ \\
$70 \mathrm{~S} 30 \mathrm{M}$ & $1.37 \mathrm{c}$ \\
$30 \mathrm{~S} 70 \mathrm{M}$ & $0.98 \mathrm{a}$ \\
$20 \mathrm{~S} 80 \mathrm{M}$ & $1.11 \mathrm{~b}$ \\
10S90M & $0.91 \mathrm{a}$ \\
\hline F TEST & \\
BM & $121.28^{* *}$ \\
\hline CV $(\%)$ & 3.12 \\
\hline
\end{tabular}

Means followed by the same lower-case letter in the column do not vary between them, according to the Tukey's test at 5\% probability. **: significant $(\mathrm{P}<0.01)$; *: significant $(\mathrm{P}<0.05)$; NS not significant; C.V: coefficient of variation. emissions when the 30S70M and 10S90M blends with 0.98 and $0.91 \mathrm{~m}^{-1}$ were used, respectively (Table 3 ). These results indicate that the smoke produced by the murumuru biodiesel combustion is lower than that produced by the soy biodiesel, making the former a better option. A $60 \%$ smoke emission reduction could be observed when comparing the highest opacity produced by the $90 \mathrm{~S} 10 \mathrm{M}$ blend, $1.51 \mathrm{~m}^{-1}$, in relation to the lowest, produced by the 90M10S blend, $0.91 \mathrm{~m}^{-1}$.

The reduction in opacity is representative and favorable to the use of biodiesel because it does not contain sulfur, containing free oxygen in the biodiesel molecule, which reduces the formation of fuel-rich areas in the combustion chamber, generating greater performance during the diffusion of combustion, increasing combustion efficiency and reduced production of particulate material (Choi et al., 2010).

Nabi et al. (2009) also found positive results when working with diesel and cotton oil biodiesel. These authors reported reductions of smoke opacity and engine power in $71 \%$ and $4.8 \%$, respectively when the engine was fueled with biodiesel and diesel. In contrast, Lima et al. (2014) found a $12.3 \%$ increase in smoke opacity when studying palm oil (dendê) biodiesel mixed with B S1800 diesel during the break-in period of the engine. This can be explained by the increase in lubricating oil viscosity, caused by unwanted and contaminant reactions. However, when fueled with B100 palm oil biodiesel smoke opacity reduced $35.12 \%$.

Yang et al. (2016) affirmed that the combination of isobutanol cooking oil and residue biodiesel is a promising fuel alternative, which produces less smoke emission in direct-injection engines. Thus, the absence of sulfur becomes an important advantage to biodiesel, since it emits no sulfuric gases, which are normally detected in the exhaust systems of engines fueled with diesel oil (Reis et al., 2013).

\section{CONCLUSIONS}

Blends with more than $80 \%$ of murumuru biodiesel promote lower fuel consumption than blends with a higher concentration of soy biodiesel. 
Regardless the biodiesel blend, the traction force at the drawbar is directly proportional to an increase in the engine rotation speed.

In smoke opacity, mixtures with more than $70 \%$ murumuru biodiesel promote less opacity than mixtures with a higher concentration of soy biodiesel.

\section{ACKNOWLEDGEMENTS, FINANCIAL SUPPORT AND FULL DISCLOSURE}

The authors thank the governmental agencies FAPESP (process n ${ }^{\circ}$ 01/09972-8), CNPQ, CAPES, and IPBEN/BIOEM for their financial support for tractor instrumentation, and the companies Coorpercitrus and Valtra for providing the tractors.

\section{REFERENCES}

ABNT - Associação Brasileira de Normas Técnicas (2001) NBR 13037: Veículos rodoviários automotores - Gás de escapamento emitido por motor em aceleração livre - Determinação da opacidade. Available at: https://www.normas.com.br/visualizar/ abnt-nbr-nm/5058/abnt-nbr13037-veiculos-rodoviariosautomotores-gas-de-escapamento-emitido-por-motor-dieselem-aceleracao-livre-determinacao-da-opacidade. Accessed on: February $11^{\text {th }}, 2021$.

Almeida RAS, Silva CAT \& Silva SL (2010) Desempenho energético de um conjunto trator-semeadora em função do escalonamento de marchas e rotações do motor. Revista Agrarian, 03:63-70.

Barbosa JC \& Maldonado-Júnior W (2015) Experimentação Agronomica \& AgroEstat - Sistema para análise estatística de ensaios agronômicos. $1^{\text {st }}$ ed. Jaboticabal, FUNEP. 396p.

Behcet R (2011) Performance and emission study of waste anchovy fish biodiesel in a diesel engine. Fuel Process, 92:11871194.

Choi YS, Nesic S \& Young D (2010) Effect of impurities on the corrosion behavior of $\mathrm{CO} 2$ transmission pipeline steel in supercritical $\mathrm{CO}^{2}$ - water environments. Environmental Science \& Technology, 44:9233-9238.

Cutini M \& Bisaglia C (2016) Development of a dynamometric vehicle to assess the drawbar performance of high-powered agricultural tractors. Journal of Terramechanics, 65:73-84.

Damanauskas V, Janulevicius A \& Pupinis G (2015) Influence of extra weight and tire pressure on fuel consumption at normal tractor slippage. Journal of Agricultural Science, 7:55-67.

Empresa de Pesquisa Energética - EPE (2019) Plano Decenal de Expansão de Energia 2029. Available at: https://www.epe.gov.br/ pt/publicacoes-dados-bertos/publicacoes/plano-decenal-deexpansao-de-energia-2029. Accessed on: February $11^{\text {th }}, 2021$.

Fiorese D, Marasca I, Fernandes BB, Sandi J, Ferreira FM \& Lanças KP (2015a) Desempenho de três tratores agrícolas em ensaios de tração. Revista de Agricultura Neotropical, 2:68-76.

Fiorese D, Sandi J, Marasca I, Ferreira FM, Spadim ER \& Lanças KP (2015b) Torque nos rodados motrizes de um trator agrícola submetido a ensaios de tração. Revista Brasileira de engenharia agrícola e Ambiental, 19:903-909.

Guimarães CC, Santos VML, Cortez JW \& Santos LDG (2018) Redução da emissão de material particulado em função da inserção de misturas do biodiesel de soja e mamona ao diesel. Engenharia Sanitária e Ambiental, 23:355-362.
International Energy Agency - IEA (2019) World Energy Outlook 2019. Available at: https://www.iea.org/. Accessed on: February $11^{\text {th }}, 2021$

Lima LP, Lopes A, Oliveira MCJ, Neves MCT \& Iamaguti PS (2014) Biodiesel de dendê em trator agrícola: opacidade da fumaça em função das condições de funcionamento do motor. Ciência \& Tecnologia, 6:22-31.

Linares P, Catalaìn H \& Meìndez V (2006) Teoria de la traccioìn de tractores agriìcolas. $2^{\text {nd }}$ ed. Madrid, Universidad Politeìcnica de Madrid. 215p.

Lopes A (2006) Biodiesel em trator agrícola: desempenho e opacidade. Teacher Thesis. Universidade Estadual Paulista, Jaboticabal. 158p.

Márquez L (2012) Tractores Agrícolas: Tecnologias y utilización. $1^{\text {st }}$ ed. Madrid, B\&h Editores. 844p.

Nabi MN, Rahman MM \& Akhter MS (2009) Biodiesel from cottonseed oil and its effect on engine performance and exhaust emissions. Applied Thermal Engineering, 29:2265-2270.

Oliveira MCJ (2016) Diesel e biodiesel de murumuru e soja: desempenho de um trator em atividades de preparo do solo. Doctoral Thesis. Universidade Estadual Paulista, Jaboticabal. $103 \mathrm{p}$.

Paula VRD, Barbosa JA, Romanelli TL, Volpato CES \& Salvador N (2016) Curvas de desempenho motor de um trator agrícola utilizando diferentes proporções de biodiesel de soja. Revista Agrogeoambiental, 8:119-127.

Pour AH, Ardebili SMS \& Sheikhdavoodi MJ (2018) Multi-objective optimization of diesel engine performance and emissions fueled with diesel-biodiesel-fusel oil blends using response surface method. Environmental Science and Pollution Research, 37:111.

Reis EF, Cunha JPB, Mateus DLS, Delmond JG \& Couto RF (2013) Desempenho e emissões de um motor-gerador ciclo diesel sob diferentes concentrações de biodiesel de soja. Revista Brasileira de Engenharia Agrícola e Ambiental, 17:565-571.

Siqueira WC, Fernandes HC, Teixeira MM, Santos NTS \& Abrahão SA (2013) Desempenho na barra de tração de um trator agrícola de pneus, alimentado com misturas de óleo diesel e óleo de soja reutilizado. Revista Ceres, 60:793-801.

TECNOMOTOR (2012) OPACER TM 133 Opacímetro de amostragem - Manual de Operação. $7^{\text {rd }}$ ed. São Carlos, Tecnomotor Eletrônica do Brasil. 26p.

Yang PM, Lin KC, Lin YC, Jhang SR \& Chen SC (2016) Emission evaluation of a diesel engine generator operating with a proportion of isobutanol as a fuel additive in biodiesel blends. Applied Thermal Engineering, 100:628-635. 